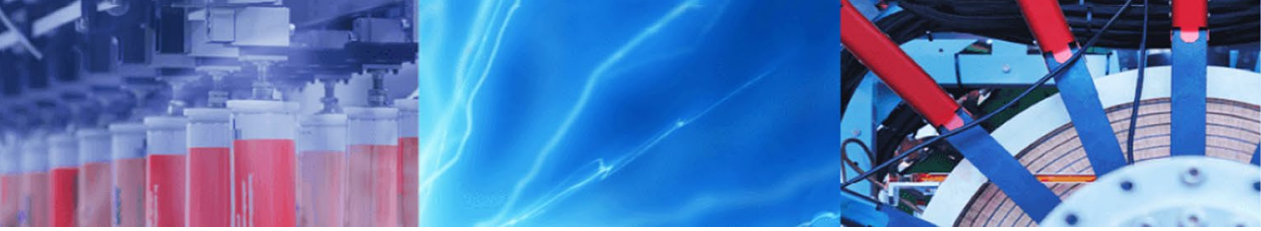

Research Article

\title{
Isolation, identification and characterization of new degradation products of Carfilzomib using high resolution mass spectrometry and nuclear magnetic resonance
}

\author{
Vijay Bommuluri ${ }^{1,2}$. Soujanya Vajjha ${ }^{1,2}$. Chidananda Swamy Rumalla ${ }^{1}$ Sudhakar Kadari ${ }^{3} \cdot$ Raju Doddipalla $^{1}$. \\ Muralidharan Kaliyaperumal $^{1} \cdot$ Raghu Babu Korupolu $^{2}$
}

(c) Springer Nature Switzerland AG 2019

\begin{abstract}
Carfilzomib is a newly approved tetra peptide epoxy ketone proteasome inhibiting agent for relapsed or refractory multiple myeloma. Very few stability studies are available on this drug. Carfilzomib (CFZ) is subjected to forced degradation under neutral, acid, base, oxidative, thermal and photolytic stress conditions as per ICH guidelines which results in formation of six degradation products in base hydrolysis. Out of six, four degradation products are reported in literature. UPLC method has been developed for separation of degradation products from CFZ drug. DP-1 and DP- 2 which are novel degradants structurally elucidated by high resolution mass spectrometry and nuclear magnetic resonance.
\end{abstract}

Keywords Carfilzomib · Proteasome inhibitor · Degradation ·HR-MS/MS · Prep-HPLC · NMR

\section{Introduction}

Carfilzomib is a selective, highly potent, second-generation proteasome inhibitor [1] it's a breakthrough target for anticancer has been achieved by Ubiquitin-proteasome pathway that has been newly accepted and approved by the FDA in 2012 for treatment of relapsed and refractory multiple myeloma [2, 3]. In July 2015, the FDA approved another expanded indication for Carfilzomib in combination with lenalidomide and dexamethasone for the treatment of patients with relapsed and refractory multiple myeloma who have received one to three prior lines of therapy that included a proteasome inhibitor and an immunomodulatory agent $[4,5]$. Carfilzomib is a synthetic tetra peptide epoxy ketone and an analogue of epoxomicin, a natural product that inhibit the proteasome [3].
Carfilzomib is an irreversible proteasome inhibitor binds to the $\mathrm{N}$-terminal threonine of the chymotrypsin-like active site of the 20Sproteasome [6]. There was no much information available about degradation behaviour of Carfilzomib and identification of its degradants in literature, where only stability paper was available [7]. The characterization data was not described earlier but few LC-MS/MS methods about drug and its biological matrixes [8-11] available in the literature. The aim of present study was to investigate the stability studies of the API drug under stress conditions which was carried out according to the international conference on harmonization (ICH) guidelines [12-16], followed by separation of degradation products through Preparative HPLC, identification and characterisation by LCMS, HRMS \& NMR.

\section{Electronic supplementary material The online version of this article (https://doi.org/10.1007/s42452-019-0921-6) contains} supplementary material, which is available to authorized users.

\footnotetext{
$\triangle$ Vijay Bommuluri, bommuluri@gmail.com | ${ }^{1}$ Department of Medicinal Chemistry, GVK Biosciences Pvt. Ltd, IDA Nacharam, Hyderabad, Telangana 500076, India. ${ }^{2}$ Department of Engineering Chemistry, Andhra University, Visakhapatnam, Andhra Pradesh 530003 , India. ${ }^{3} \mathrm{~A} 1$ Phama Solutions, Hyderabad, Telangana 500076, India.
} 


\section{Materials and methods}

\subsection{Chemicals and reagents}

Carfilzomib (CFZ, purity $\geq 99 \%$ ) drug was gifted by A1 green pharma solutions, Hyderabad. Formic acid, Ammonium Bicarbonate, and acetonitrile (LCMS grade), hydrochloric acid ( $\geq 37 \%$, puriss. p.a.), sodium hydroxide, were purchased from Sigma Aldrich (Munich, Germany). Hydrogen peroxide (30\%, Ph.Eur.) from MERCK, Dimethyl sulfoxide- $\mathrm{d}_{6}$ containing $0.03 \%(\mathrm{v} / \mathrm{v})$ TMS (Cambridge isotope limited) Milli-Q water was prepared using a Millipore purification system (Merck-Millipore, armstadt, Germany).

\subsection{High resolution mass spectrometry}

ACQUITY BEH C18, $2.1 \mathrm{~mm} \times 50 \mathrm{~mm}, 1.7 \mu \mathrm{m}$ was selected as the stationary phase, A mixture of $0.05 \%$ formic acid (A) and acetonitrile (B) was used in the following gradient method: 0-0.4 min 3\% B, 0.4-2.5 min 98\% B, 3.5-4.5 min $3 \%$ B. A flow rate of $0.6 \mathrm{~mL} / \mathrm{min}$, a column temperature of $30^{\circ} \mathrm{C}$ and injection volume of $1 \mu \mathrm{L}$ were used. Dionex Ultimate 3000 UHPLC Thermo Q-Exactive. ESI + mode with the following setup: Spray Voltage: $3.50 \mathrm{kV}$, Capillary Temp: $270{ }^{\circ} \mathrm{C}$ Aux Gas Heater Temp: $450^{\circ} \mathrm{C}$, Source Temperature: $140{ }^{\circ} \mathrm{C}$; Desolvation Temperature: $300^{\circ} \mathrm{C}$; Cone Gas: $50 \mathrm{~L} / \mathrm{h}$; Desolvation Gas: 650 L/h. Mass Range: 100-1500, Sample was analyzed in both the modes (Positive and Negative). Caffeine was used as an internal standard. Mass data was processed with Thermo Xcalibur Version: 3.0.63.

\subsection{Preparative HPLC}

Preparative liquid chromatography is a widely used dominant purification technique, versatile, robust for the isolation of pharmaceutical impurities. Preparative HPLC-MS is now routinely used for high throughput purification for targeted as well as random libraries and has a major impact on the purity of our compound collections Preparative HPLC equipped with water pump module 2545 , Waters PDA detector module 2998 at $215 \mathrm{~nm}$. Degradation products are isolated by Reversed-Phase Preparative HPLC equipped with an automated fraction collector and photodiode array detector. Using X-Bridge $19 \mathrm{~mm} \times 250 \mathrm{~mm}$, $5 \mu \mathrm{m}$ Waters as stationary phase and the mobile phase (A) $5 \mathrm{mM}$ Ammonium Bicarbonate, and (B) acetonitrile. gradient method: $0-1.0$ min $10 \% \mathrm{~B}, 1.1-8.0 \mathrm{~min} 60 \% \mathrm{~B}$,
$8.1-12 \min 60 \% \mathrm{~B}, 12.1-18 \min 98 \% \mathrm{~B}, 18.1-20 \min 10 \%$ $B$, at a flow rate of $19.0 \mathrm{ml} / \mathrm{min}$. Injection volume was $400.0 \mu \mathrm{L}$, and the detection wavelength was $215 \mathrm{~nm}$. Aliquot of $10 \mathrm{mg} / \mathrm{mL}$ of the sample was prepared to load on to the preparative column. Target degradation fractions were collected after every injection and freezed immediately to avoid decomposition of the degradation products. These fractions were subjected to lyophilisation to get the pure compound without any solvents and salts.

\subsection{Nuclear magnetic resonance spectroscopy}

NMR analysis of Carfilzomib (API) and its isolated impurities were carried on Bruker AVANCE NEO $400 \mathrm{MHz}$ NMR instrument. All the NMR analysis has been performed at $298 \mathrm{~K}$ probe temperature with fine automatic tuning and matching for the frequency of respective nuclei. $1 \mathrm{H} \mathrm{nmr}$ spectra were referenced to tetra methyl Silane (TMS) singlet at zero (0) ppm and referenced DMSO-D6 septet at $39.5 \mathrm{ppm}$ in carbon $\mathrm{nmr}$.

One dimensional (1D) analysis ${ }^{1} \mathrm{H}$ NMR data acquired and processed with following parameters like spectral width $(\mathrm{SW})=19.53 \mathrm{ppm}$, relaxation delay time $(\mathrm{D} 1)=1 \mathrm{~s}$, number of scans $(N S)=16$, number of data points $(T D)=64 k$, $90^{\circ}$ pulse width $(P 1)=10 \mu \mathrm{s}$, acquisition time $(A Q)=4.19 \mathrm{~s}$, operating spectrometer frequency (SF) $=400.13 \mathrm{MHz}$ and line broadening $(\mathrm{LB})=0.3 \mathrm{~Hz} .{ }^{13} \mathrm{C}$ NMR data acquired and processed with following parameters like spectra width $(\mathrm{SW})=236.79 \mathrm{ppm}$, relaxation delay $(\mathrm{D} 1)=2 \mathrm{~s}$, number of scans $(N S)=2000$, data points $(T D)=64 \mathrm{k}, 90^{\circ}$ Pulse width $(P 1)=10 \mu \mathrm{s}$, acquisition time $(A Q)=1.37 \mathrm{~s}$ line broadening $(L B)=1.0 \mathrm{~Hz}$ spectrometer frequency $(S F)=100.53 \mathrm{MHz}$ parameters.

Two dimensional (2D) analysis Homonuclear ${ }^{1} \mathrm{H}-{ }^{1} \mathrm{H}$ gDQCOSY experiment has been performed to know the proton-proton correlations with following parameters $(\mathrm{SW})=14.71 \mathrm{ppm}$ in both $\mathrm{F} 1$ \& $\mathrm{F} 2$ projections, relaxation delay time (D1) $=2 \mathrm{~s}$, number of scans $(N S)=16$, number of data points (TD) $=2048(F 2) \& 256(F 1)$, dummy scans $(D S)=4.1 \mathrm{H}-13 \mathrm{C} \mathrm{gHSQC}$ was done to know the ${ }^{1} \mathrm{~J}$ correlations between proton and carbon and $\mathrm{gHMBC}$ has been performed to reveal the exact structure of degradation product(s).

\subsection{Forced degradation studies}

$50 \mathrm{mg}$ of CFZ was accurately weighed in a $50 \mathrm{~mL}$ volumetric flask dissolved in acetonitrile and diluted with the same solvent to reach a final concentration of $1 \mathrm{mg} / \mathrm{mL}$. 
Fig. 1 UPLC degradation chromatograms base (a), acid (b), photolytic (c), neutral (d), hydrogen peroxide (e)

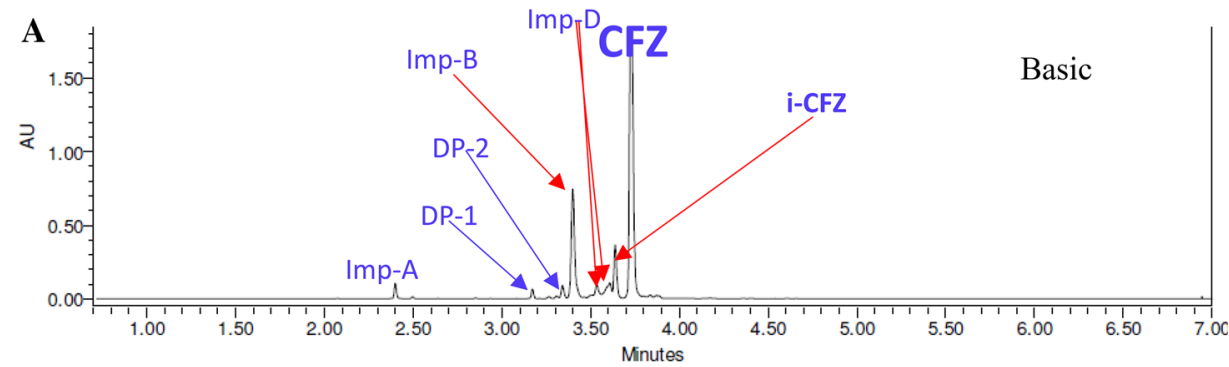

B

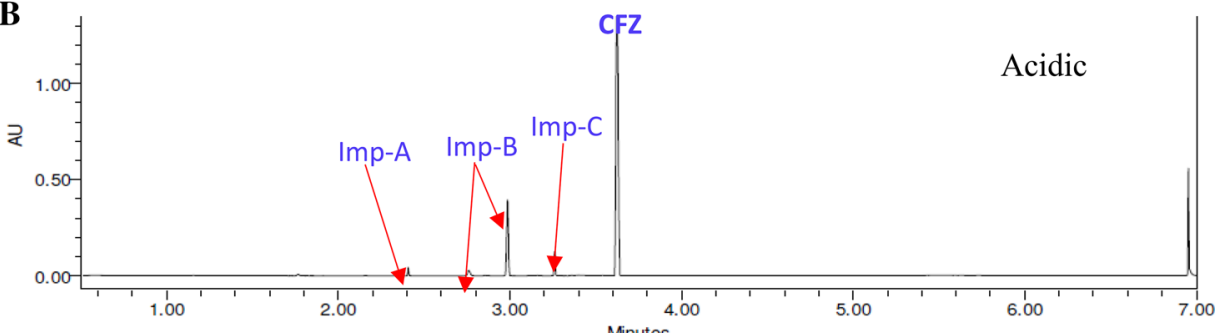

C

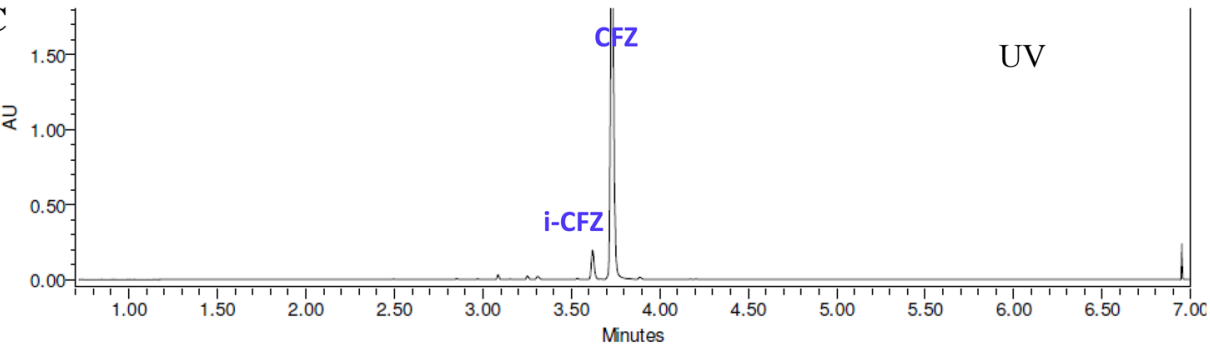

D

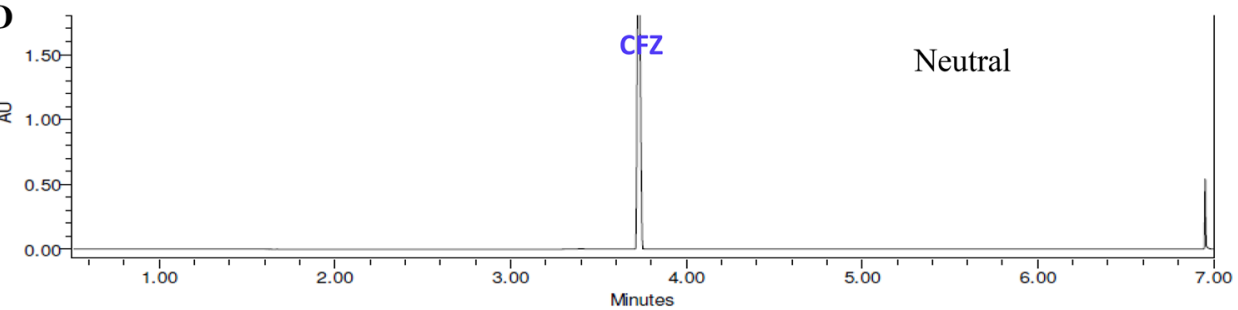

$\mathbf{E}$

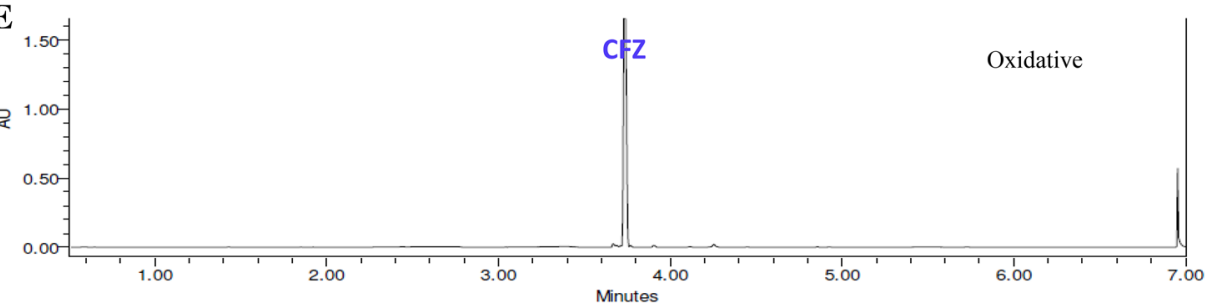

CFZ is forcibly degraded under elevated temperature, photolytic degradation, acid hydrolysis, base hydrolysis, water hydrolysis and oxidation. Stock solution of CFZ was mixed with a given volume of the degradation media (either water, $0.1 \mathrm{~N} \mathrm{HCl}, 0.01 \mathrm{~N} \mathrm{NaOH}$, or $0.3 \% \mathrm{H}_{2} \mathrm{O}_{2}$ ) in a ratio of $1: 1(\mathrm{v} / \mathrm{v})$. Samples were maintained at either room temperature $\left(18-20^{\circ} \mathrm{C}\right)$ or at $60^{\circ} \mathrm{C}$ for $1 \mathrm{~h}$. For Acid hydrolysis stock solution of $\mathrm{CFZ}$ is mixed with $1 \mathrm{~N} \mathrm{HCl}$ solution kept at room temperature $\left(18-20^{\circ} \mathrm{C}\right.$ ) and $60^{\circ} \mathrm{C}$. For Base hydrolysis stock solution of CFZ is mixed with $0.01 \mathrm{~N} \mathrm{NaOH}$ solution, white precipitate was formed, the sample was not clear even after sonication, then solution is diluted with acetonitrile and mixed well clear solution is observed kept at room temperature and at $60^{\circ} \mathrm{C}$. For oxidation forcibly degraded the sample by using $0.3 \% \mathrm{H}_{2} \mathrm{O}_{2}$ at $60{ }^{\circ} \mathrm{C}$ temperature. Photolytic degradation was carried out in solution and solid state, placed in fused-quartz cuvette and exposed to UV light (100 W Xenon ozone-free arc lamp, with illuminance $12,500 \mathrm{~lx}$ ) for $48 \mathrm{~h}$. At the end of the experiments samples were neutralized, if required diluted with acetonitrile:water (1:1). Degradation products are isolated by Preparative HPLC and Characterised by HR-MS and NMR. 
Fig. 2 Preparative chromatogram of base degradants

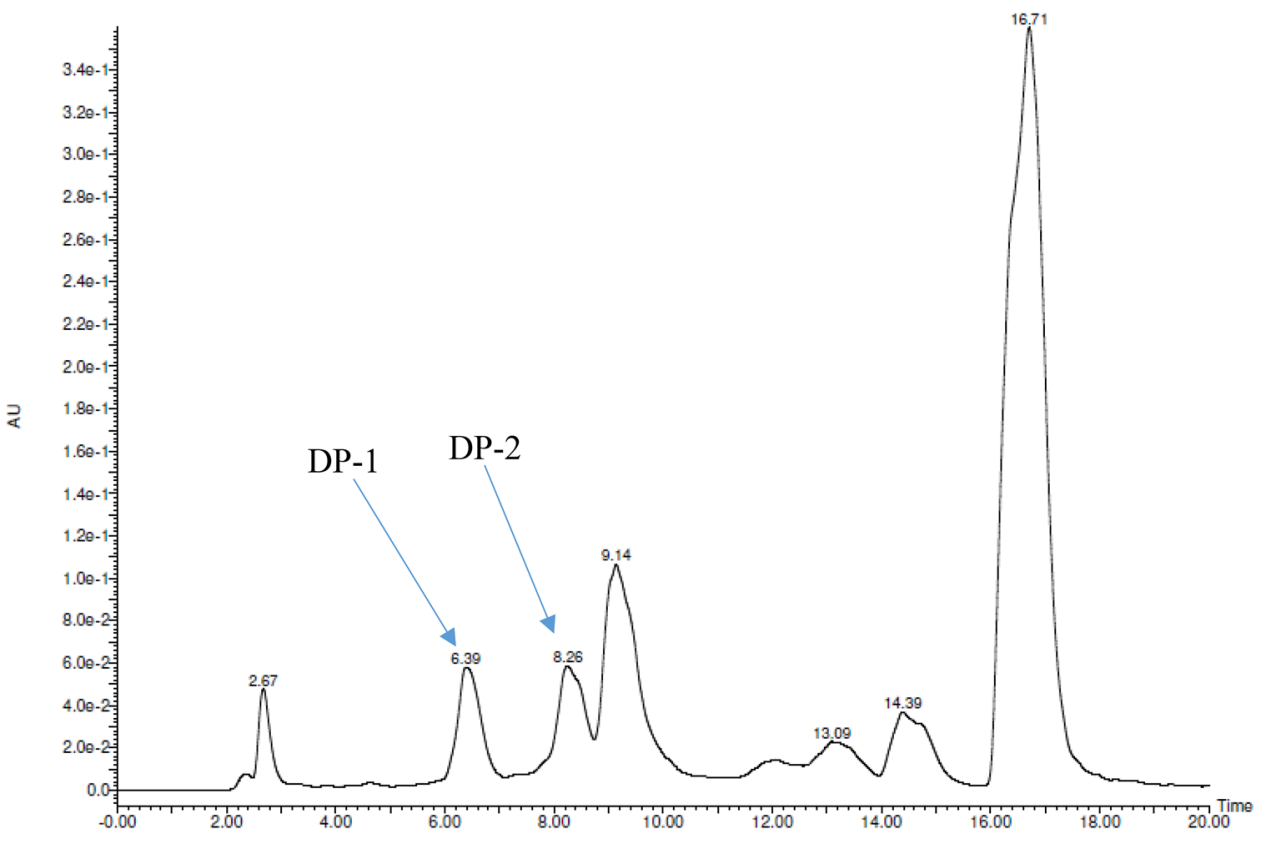

\section{Results and discussion}

CFZ was stable in neutral and oxidative conditions. Degradation was observed in acid, base, thermal and photolytic stress conditions (Fig. 1). Four degradants in acidic, six degradation products in basic, Out of six Imp-A, Imp-B, two Imp-D peaks and I-CFZ are the degradation products that are described in Sestak et al. [7] two novel degradants DP-1 and DP-2 which are not reported in the literature. HR-MS/ MS data of all the degradants showed in additional data. No degradation observed in oxidative and one major degradation product in photolytic are observed. Degradation products (DP-1\& DP-2) were isolated by Preparative HPLC (Fig. 2) using the described method in the Sect. 2.3. Isolation of the degradants were found to be difficult because the compounds are highly unstable in milder basic conditions even at room temperature. Due to stability issues, fractions are collected at $-80^{\circ} \mathrm{C}$ and lyophilized. Identification and Characterisation was carried out by NMR \& HR-MS/MS Studies. HR-MS/MS fragmentation of CFZ provides an essential information. HR-MS/MS showed protonated molecular ion $[\mathrm{M}+\mathrm{H}]^{+}$at $\mathrm{m} / \mathrm{z} 720.4323$ with mass error of $-1.05 \mathrm{ppm}$. The major fragmentation ions of CFZ were 402.2383, 289.1541, 261.1594 \& 100.076 (Supplementary fig. S1).

\subsection{Structural elucidation of DP-1}

Molecular weight of the degradant product is $\mathrm{m} / \mathrm{z}$ $704.4008[\mathrm{M}+\mathrm{H}]^{+}$which is 16 units less from the CFZ (m/z 719). CFZ and DP-1 are having odd molecular weight which indicates presence of odd number of nitrogen's in the molecule according to nitrogen's rule. The major fragmentation ions of DP-1 were 672.4101, 402.2382, $289.1544,261.1595 \& 100.0760$ (Supplementary fig. S2). 672.4101 Fragment is formed by the loss of methoxy group and remaining fragmentation showed same as fragmentation behaviour of CFZ. This was further confirmed by NMR studies. In the proton NMR of DP-1, the epoxide ring protons got disappear at $2.9 \mathrm{ppm} \& 3.1 \mathrm{ppm}$ and appeared a singlet methyl at 2.69 ppm (Table 1). The quaternary carbon (C40) of epoxide ring in API is seen at 58.7 ppm and same carbon C49 in DP-1 Deshields to downfield at $102.8 \mathrm{ppm}$. A significant change was observed for (C42) carbon, in API it was seen as tertiary carbon (chiral $\mathrm{CH}$ center) whereas in DP-1 it has become quaternary carbon, the chemical shift variation was observed from 49.1 to 90.6 ppm and also multiplicity of one of the $-\mathrm{NH}$ proton, where doublet has become singlet at $7.3 \mathrm{ppm}$. Apart from the 1D analysis, 2D analysis (gCOSY, gHSQC, gHMBC) also performed to make more precise structure (Figure 3$)$. Long range couplings $\left({ }^{3} \mathrm{~J},{ }^{2} \mathrm{~J}\right)$ from Methoxy (H49), Methylene (H44), Methine (H45) and Enamine $\mathrm{NH} 43$ protons were showing correlations to the $\mathrm{C} 42$ carbon. Methyl (H51) was showing ${ }^{3} \mathrm{~J}$ correlation with a- $\beta$ unsaturated carbonyl carbon at 199.8 ppm and $\beta$-carbon at $175.8 \mathrm{ppm}$. Other than methyl (H51) correlation to $\beta$-carbon, it is also showing correlations with benzylic protons $(\mathrm{H} 32)$, one of the chiral $\mathrm{CH}$ proton $(\mathrm{H} 31)$ and Enamine $\mathrm{NH} 43$ proton (Fig. 4). Rest of the structure and connectivity's are unchanged, apart from these key observations. Based on all NMR experimental data, it 
Table $1{ }^{1} \mathrm{H}$ and ${ }^{13} \mathrm{C}$ NMR data of Carfilzomib and DP-1

\begin{tabular}{|c|c|c|c|c|c|c|c|}
\hline \multicolumn{4}{|c|}{ Carfilzomib } & \multicolumn{4}{|l|}{ DP-1 } \\
\hline Atom no & $\begin{array}{l}\text { Type of } \\
\text { atom }\end{array}$ & $\begin{array}{l}1 \mathrm{H} \text { chemical shift }(\mathrm{ppm}) \\
\text { coupling const }(\mathrm{J})\end{array}$ & $\begin{array}{l}13 C \text { chemical } \\
\text { shifts (ppm) }\end{array}$ & $\begin{array}{l}\text { Atom } \\
\text { no }\end{array}$ & $\begin{array}{l}\text { Type of } \\
\text { atom }\end{array}$ & $\begin{array}{l}1 \mathrm{H} \text { chemical shift (ppm) } \\
\text { coupling const }(\mathrm{J})\end{array}$ & $\begin{array}{l}13 C \text { chemical } \\
\text { shifts (ppm) }\end{array}$ \\
\hline 1 & $\mathrm{CH}_{2}$ & $3.60(\mathrm{t}, 4.56 \mathrm{~Hz}, 2 \mathrm{H})$ & 66.12 & 1 & $\mathrm{CH}_{2}$ & $3.61(\mathrm{t}, 4.36 \mathrm{~Hz}, 2 \mathrm{H})$ & 66.19 \\
\hline 2 & $\mathrm{CH}_{2}$ & $2.43(\mathrm{t}, 4.56 \mathrm{~Hz}, 2 \mathrm{H})$ & 53.15 & 2 & $\mathrm{CH}_{2}$ & $2.44(\mathrm{t}, 4.36 \mathrm{~Hz}, 2 \mathrm{H})$ & 53.22 \\
\hline 3 & $\mathrm{~N}$ & - & - & 3 & $\mathrm{~N}$ & - & - \\
\hline 4 & $\mathrm{CH}_{2}$ & $2.43(\mathrm{t}, 4.56 \mathrm{~Hz}, 2 \mathrm{H})$ & 53.15 & 4 & $\mathrm{CH}_{2}$ & $2.44(\mathrm{t}, 4.36 \mathrm{~Hz}, 2 \mathrm{H})$ & 53.22 \\
\hline 5 & $\mathrm{CH}_{2}$ & $3.60(\mathrm{t}, 4.56 \mathrm{~Hz}, 2 \mathrm{H})$ & 66.12 & 5 & $\mathrm{CH}_{2}$ & $3.61(\mathrm{t}, 4.36 \mathrm{~Hz}, 2 \mathrm{H})$ & 66.19 \\
\hline 6 & 0 & - & - & 6 & $\mathrm{O}$ & - & - \\
\hline 7 & $\mathrm{CH}_{2}$ & $2.94(\mathrm{~d}, 15.00 \mathrm{~Hz}, 1 \mathrm{H}) 2.96(\mathrm{~d}, 15.00 \mathrm{~Hz}, 1 \mathrm{H})$ & 61.3 & 7 & $\mathrm{CH}_{2}$ & $2.97(\mathrm{~d}, 15.41 \mathrm{~Hz}, 1 \mathrm{H}) 3.00(\mathrm{~d}, 15.41 \mathrm{~Hz}, 1 \mathrm{H})$ & 61.38 \\
\hline 8 & $\mathrm{C}$ & - & 168.78 & 8 & C & - & 169.13 \\
\hline 9 & $\mathrm{O}$ & - & - & 9 & $\mathrm{O}$ & - & - \\
\hline 10 & $\mathrm{NH}$ & $7.87(\mathrm{~d}, 8.30 \mathrm{~Hz}, 1 \mathrm{H})$ & - & 10 & $\mathrm{NH}$ & 7.94(d, $8.20 \mathrm{~Hz}, 1 \mathrm{H})$ & - \\
\hline 11 & $\mathrm{CH}$ & $4.34(\mathrm{~m}, 1 \mathrm{H})$ & 51.72 & 11 & $\mathrm{CH}$ & $4.36(\mathrm{~m}, 1 \mathrm{H})$ & 51.95 \\
\hline 12 & $\mathrm{CH}_{2}$ & $1.79(\mathrm{~m}, 1 \mathrm{H}) 1.88(\mathrm{~m}, 1 \mathrm{H})$ & 34.28 & 12 & $\mathrm{CH}_{2}$ & $1.82(\mathrm{~m}, 1 \mathrm{H}) 1.89(\mathrm{~m}, 1 \mathrm{H})$ & 34.44 \\
\hline 13 & $\mathrm{CH}_{2}$ & $2.49(\mathrm{~m}, 2 \mathrm{H})$ & 31.35 & 13 & $\mathrm{CH}_{2}$ & $2.50(\mathrm{~m}, 2 \mathrm{H})$ & 31.51 \\
\hline 14 & $\mathrm{C}$ & - & 141.48 & 14 & $\mathrm{C}$ & - & 141.49 \\
\hline 15 & $\mathrm{CH}$ & $7.15(\mathrm{~m}, 1 \mathrm{H})$ & 128.21 & 15 & $\mathrm{CH}$ & $7.16(\mathrm{~m}, 1 \mathrm{H})$ & 128.37 \\
\hline 16 & $\mathrm{CH}$ & 7.27(m, 1H) & 128.23 & 16 & $\mathrm{CH}$ & 7.28(m, 1H) & 128.31 \\
\hline 17 & $\mathrm{CH}$ & $7.17(\mathrm{~m}, 1 \mathrm{H})$ & 125.74 & 17 & $\mathrm{CH}$ & 7.18(m, 1H) & 125.89 \\
\hline 18 & $\mathrm{CH}$ & 7.27(m, 1H) & 128.23 & 18 & $\mathrm{CH}$ & 7.28(m, 1H) & 128.31 \\
\hline 19 & $\mathrm{CH}$ & 7.15(m, 1H) & 128.21 & 19 & $\mathrm{CH}$ & 7.16(m, 1H) & 128.37 \\
\hline 20 & $\mathrm{C}$ & - & 170.9 & 20 & $\mathrm{C}$ & - & 171.17 \\
\hline 21 & $\mathrm{O}$ & - & - & 21 & $\mathrm{O}$ & - & - \\
\hline 22 & $\mathrm{NH}$ & $8.05(\mathrm{~d}, 8.20 \mathrm{~Hz}, 1 \mathrm{H})$ & - & 22 & $\mathrm{NH}$ & $8.23(\mathrm{~d}, 8.10 \mathrm{~Hz}, 1 \mathrm{H})$ & - \\
\hline 23 & $\mathrm{CH}$ & $4.28(\mathrm{td}, 8.52,6.00 \mathrm{~Hz}, 1 \mathrm{H})$ & 51.02 & 23 & $\mathrm{CH}$ & 4.32(m, 1H) & 51.03 \\
\hline 24 & $\mathrm{CH}_{2}$ & $1.36(\mathrm{~m}, 2 \mathrm{H})$ & 40.74 & 24 & $\mathrm{CH}_{2}$ & $1.42(\mathrm{~m}, 2 \mathrm{H})$ & 40.12 \\
\hline 25 & $\mathrm{CH}$ & $1.51(\mathrm{~m}, 1 \mathrm{H})$ & 24.05 & 25 & $\mathrm{CH}$ & $1.49(\mathrm{~m}, 1 \mathrm{H})$ & 24.2 \\
\hline 26 & $\mathrm{CH}_{3}$ & $0.83(\mathrm{~d}, 6.58 \mathrm{~Hz}, 3 \mathrm{H})$ & 22.94 & 26 & $\mathrm{CH}_{3}$ & $0.80(\mathrm{~d}, 6.40 \mathrm{~Hz}, 3 \mathrm{H})$ & 22.8 \\
\hline 27 & $\mathrm{CH}_{3}$ & $0.79(\mathrm{~d}, 6.58 \mathrm{~Hz}, 3 \mathrm{H})$ & 21.56 & 27 & $\mathrm{CH}_{3}$ & $0.84(\mathrm{~d}, 6.40 \mathrm{~Hz}, 3 \mathrm{H})$ & 21.77 \\
\hline 28 & $\mathrm{C}$ & - & 171.45 & 28 & $C$ & - & 171.52 \\
\hline 29 & $\mathrm{O}$ & - & - & 29 & $\mathrm{O}$ & - & - \\
\hline 30 & $\mathrm{NH}$ & 7.94(d, 8.25 Hz, 1H) & - & 30 & $\mathrm{NH}$ & $8.55(\mathrm{~d}, 7.89 \mathrm{~Hz}, 1 \mathrm{H})$ & - \\
\hline 31 & $\mathrm{CH}$ & $4.52(\mathrm{td}, 8.62,4.73 \mathrm{~Hz}, 1 \mathrm{H})$ & 52.91 & 31 & $\mathrm{CH}$ & $5.01(q, 7.89 \mathrm{~Hz}, 1 \mathrm{H})$ & 48.73 \\
\hline 32 & $\mathrm{CH}_{2}$ & $\begin{array}{l}2.76(\mathrm{dd}, 14.10,9.10 \mathrm{~Hz}, 1 \mathrm{H}) 2.97(\mathrm{dd}, \\
\quad 14.10,4.73 \mathrm{~Hz}, 1 \mathrm{H})\end{array}$ & 37.38 & 32 & $\mathrm{CH}_{2}$ & $\begin{array}{l}2.96(d d, 13.67,3.00 \mathrm{~Hz}, 1 \mathrm{H}) 3.07(\mathrm{dd}, \\
\quad 13.67,7.70 \mathrm{~Hz}, 1 \mathrm{H})\end{array}$ & 37.61 \\
\hline 33 & $\mathrm{C}$ & - & 137.4 & 33 & $\mathrm{C}$ & - & 136.74 \\
\hline 34 & $\mathrm{CH}$ & 7.15(m, 1H) & 129.02 & 34 & $\mathrm{CH}$ & $7.20(\mathrm{~m}, 1 \mathrm{H})$ & 129.07 \\
\hline 35 & $\mathrm{CH}$ & 7.19(m, 1H) & 127.87 & 35 & $\mathrm{CH}$ & 7.19(m, 1H) & 128.16 \\
\hline 36 & $\mathrm{CH}$ & 7.08(m, 1H) & 126.11 & 36 & $\mathrm{CH}$ & 7.13(m, 1H) & 126.61 \\
\hline 37 & $\mathrm{CH}$ & 7.19(m, 1H) & 127.87 & 37 & $\mathrm{CH}$ & 7.19(m, 1H) & 128.16 \\
\hline 38 & $\mathrm{CH}$ & 7.15(m, 1H) & 129.02 & 38 & $\mathrm{CH}$ & $7.20(\mathrm{~m}, 1 \mathrm{H})$ & 129.07 \\
\hline 39 & $\mathrm{C}$ & - & 170.98 & 39 & C & - & 175.84 \\
\hline 40 & $\mathrm{O}$ & - & - & 40 & C & - & 102.89 \\
\hline 41 & $\mathrm{NH}$ & 8.23(d, 7.47 Hz, 1H) & - & 41 & $\mathrm{C}$ & - & 199.85 \\
\hline 42 & $\mathrm{CH}$ & $4.36(\mathrm{~m}, 1 \mathrm{H})$ & 49.19 & 42 & $\mathrm{C}$ & - & 90.64 \\
\hline 43 & $\mathrm{CH}_{2}$ & $1.31(\mathrm{~m}, 2 \mathrm{H})$ & 38.49 & 43 & $\mathrm{NH}$ & $7.37(\mathrm{~s}, 1 \mathrm{H})$ & - \\
\hline 44 & $\mathrm{CH}$ & $1.62(\mathrm{~m}, 1 \mathrm{H})$ & 24.42 & 44 & $\mathrm{CH}_{2}$ & $1.29,1.44(\mathrm{~m}, 2 \mathrm{H})$ & 44.33 \\
\hline 45 & $\mathrm{CH}_{3}$ & $0.88(\mathrm{~d}, 6.37 \mathrm{~Hz}, 3 \mathrm{H})$ & 23.12 & 45 & $\mathrm{CH}$ & $1.68(m, 1 \mathrm{H})$ & 22.8 \\
\hline 46 & $\mathrm{CH}_{3}$ & $0.81(\mathrm{~d}, 6.37 \mathrm{~Hz}, 3 \mathrm{H})$ & 20.98 & 46 & $\mathrm{CH}_{3}$ & $0.75(\mathrm{~d}, 6.58 \mathrm{~Hz}, 3 \mathrm{H})$ & 24.04 \\
\hline 47 & $\mathrm{C}$ & - & 208.12 & 47 & $\mathrm{CH}_{3}$ & $0.86(\mathrm{~d}, 6.68 \mathrm{~Hz}, 3 \mathrm{H})$ & 24.64 \\
\hline 48 & $\mathrm{O}$ & - & - & 48 & $\mathrm{O}$ & - & - \\
\hline 49 & $\mathrm{C}$ & - & 58.76 & 49 & $\mathrm{CH}_{3}$ & $2.69(\mathrm{~s}, 3 \mathrm{H})$ & 49.72 \\
\hline 50 & $\mathrm{CH}_{3}$ & $1.39(\mathrm{~s}, 3 \mathrm{H})$ & 16.36 & 50 & $\mathrm{O}$ & - & - \\
\hline
\end{tabular}


Table 1 (continued)

\begin{tabular}{|c|c|c|c|c|c|c|c|}
\hline \multicolumn{4}{|c|}{ Carfilzomib } & \multicolumn{4}{|l|}{ DP-1 } \\
\hline Atom no & $\begin{array}{l}\text { Type of } \\
\text { atom }\end{array}$ & $\begin{array}{l}1 \mathrm{H} \text { chemical shift }(\mathrm{ppm}) \\
\text { coupling const }(\mathrm{J})\end{array}$ & $\begin{array}{l}13 C \text { chemical } \\
\text { shifts (ppm) }\end{array}$ & $\begin{array}{l}\text { Atom } \\
\text { no }\end{array}$ & $\begin{array}{l}\text { Type of } \\
\text { atom }\end{array}$ & $\begin{array}{l}1 \mathrm{H} \text { chemical shift }(\mathrm{ppm}) \\
\text { coupling const }(\mathrm{J})\end{array}$ & $\begin{array}{l}13 C \text { chemical } \\
\text { shifts (ppm) }\end{array}$ \\
\hline 51 & $\mathrm{O}$ & - & - & 51 & $\mathrm{CH}_{3}$ & $1.39(\mathrm{~s}, 3 \mathrm{H})$ & 5.62 \\
\hline 52 & $\mathrm{CH}_{2}$ & $2.95(\mathrm{~d}, 5.18 \mathrm{~Hz}, 1 \mathrm{H}) 3.10(\mathrm{~d}, 5.18 \mathrm{~Hz}, 1 \mathrm{H})$ & 51.44 & & & & \\
\hline
\end{tabular}

$s$ singlet, $d$ doublet, $t$ triplet, $d d$ doublet of doublet, $m$ multiplet, $t d$ triplet of doublet

has been observed that the epoxide ring (Oxirane) got opened and formed newly formed dihydro pyrrolidine 3-one derivative. Plausible mechanism of DP-1 showed in the Fig. 5.

\subsection{Structural elucidation of DP-2}

The HR-MS/MS showed a protonated molecular ion peak at $\mathrm{m} / \mathrm{z} 702.4230[\mathrm{M}+\mathrm{H}]^{+}$corresponding to molecular formula $\mathrm{C}_{40} \mathrm{H}_{56} \mathrm{~N}_{5} \mathrm{O}_{6}$. The major fragmentation ions of DP-2 were 670.3954, 519.2952, 402.2382 \& 231.1489 (Supplementary fig. S3 \& S4). The fragmented ion 670.3954 formed by the loss of methoxy group, 519.2952 fragmentation formed by the loss of 2-isobutyl-2-methoxy-4-methyl-1,2-dihydro-3H-pyrrol3-one group and remaining fragmentation behaviour showed in the Fig. 6 . The ${ }^{1} \mathrm{H}$ NMR spectrum revealed that the DP-2 has 42 aliphatic protons, 10 aromatic protons and three exchangeable protons. The ${ }^{13} \mathrm{C}$ NMR spectrum showed 17 aliphatic carbons and 14 aromatic carbons. Further, the assignments of ${ }^{1} \mathrm{H}$ and ${ }^{13} \mathrm{C}$ NMR signals are made by analysis of COSY, HMBC (Fig. 7) and HSQC spectra. One amidic $\mathrm{NH} 10$ doublet is seen at $8.17 \mathrm{ppm}$ and other $\mathrm{NH} 24$ as broader singlet at $9.41 \mathrm{ppm}$ (Table 2). As discussed in DP-1 structure elucidation, same rearrangement has occurred in DP-2, by opening of the epoxide ring and forming dihydro pyrrolidine 3-one derivative.
Only difference between the API and DP-2 NMR data is that one of the chiral - $\mathrm{CH}$ carbon $(\mathrm{CH} 31)$ in API has disappeared at $52.91 \mathrm{ppm}$ and same carbon (C25) in DP-2 appeared at $75.72 \mathrm{ppm}$ as quaternary carbon. There are two doublets $\left(\mathrm{CH}_{2} 31\right) 3.08,3.83 \mathrm{ppm}$ with $13.6 \mathrm{~Hz}$ coupling constant and are attached to same carbon at $41.79 \mathrm{ppm}$. These two doublets were showing correlation with C32, C33, C37, C25 and C26. We have observed only two chiral $\mathrm{CH} 11$ \& $\mathrm{CH} 22$ carbons at $55.72 \mathrm{ppm}$ and $48.91 \mathrm{ppm}$ it was further confirmed by ${ }^{1} \mathrm{~J} \mathrm{CH}$ correlations in gHSQC data (Fig. 8). Structure of the DP-2 has been deduced and concluded that one more ring cyclisation has taken place between the $\mathrm{C} 25$ and N21 atoms. To the best of our knowledge DP-2 structure was assigned by using NMR and HR-MS/MS data. Plausible mechanism of DP-2 showed in the Fig. 9.

\section{Conclusion}

The present research work describes about identification and characterization of two new degradants observed in base hydrolysis which are not yet documented in the literature. Chemical structure was assigned by using HR-MS/MS and NMR studies. Carfilzomib stable at neutral \& oxidation, extremely degraded in Acid and Base hydrolysis and susceptible to photo degradation. 
Fig. 3 a COSY spectrum of DP-1, b HSQC spectrum of DP-1
A

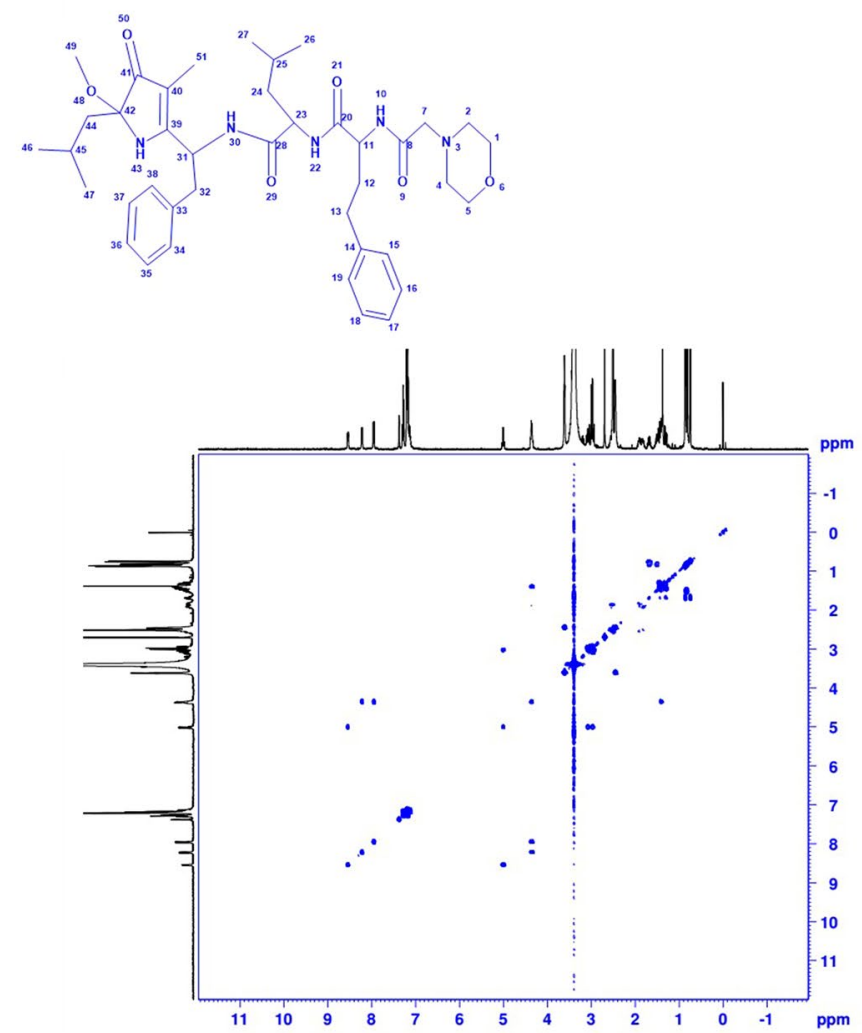

B

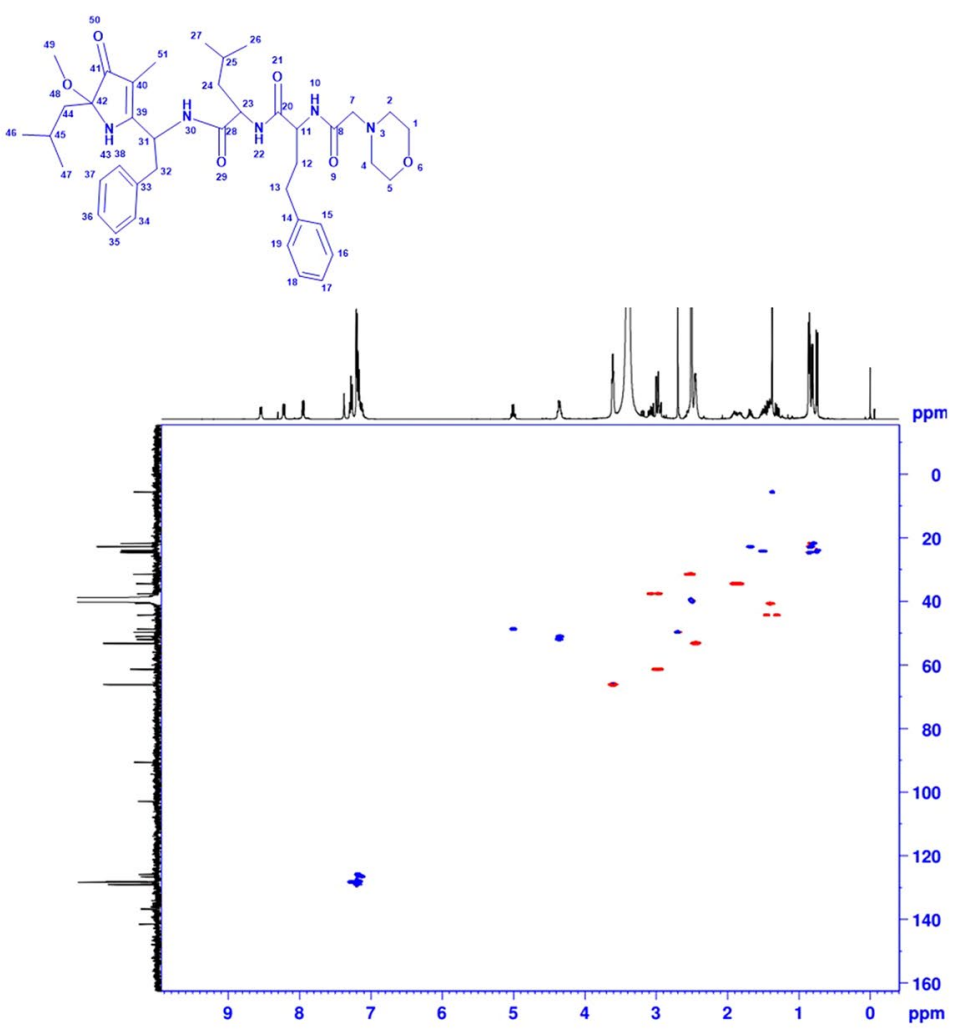


Fig. 4 HMBC spectrum of DP-1
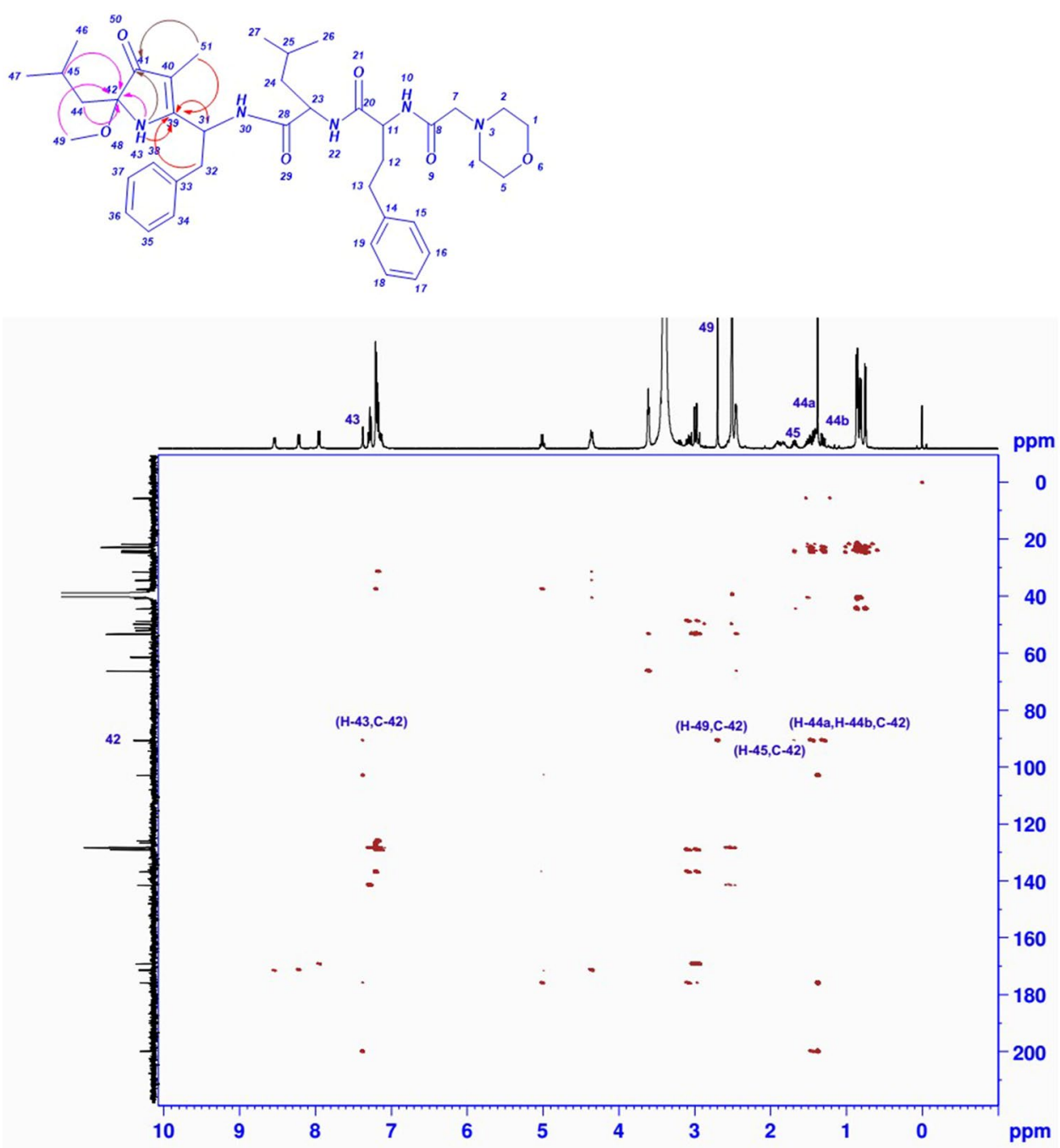

The chemical name of degradation product DP-1 is $\mathrm{N}$-(1-(5-isobutyl-5-methoxy-3-methyl-4-oxo-4,5dihydro-1H-pyrrol-2-yl)-2-phenylethyl)-4-methyl-2(2-(2-morpholinoacetamido)-4-Phenylbutanamido) pentanamide, DP-2 as N-(1-(2-benzyl-5-isobutyl-2-(5isobutyl-5-methoxy-3-methyl-4-oxo-4,5-dihydro-1H-pyrrol-2-yl)-4-oxoimidazolidin-1-yl)-1-oxo-4-phenylbutan2-yl)-2-morpholinoacetamide. 
Fig. 5 Plausible mechanism of DP-1

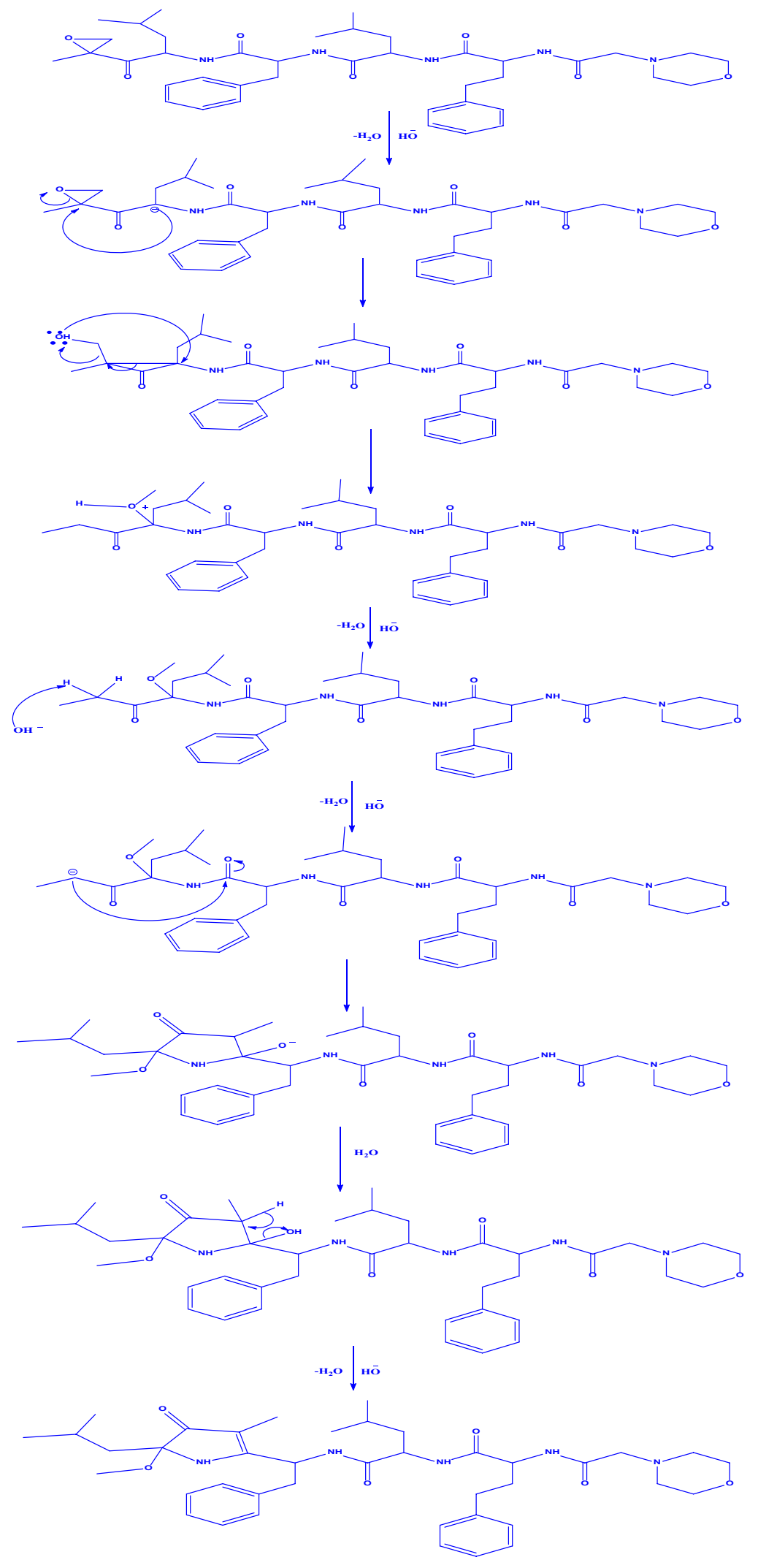




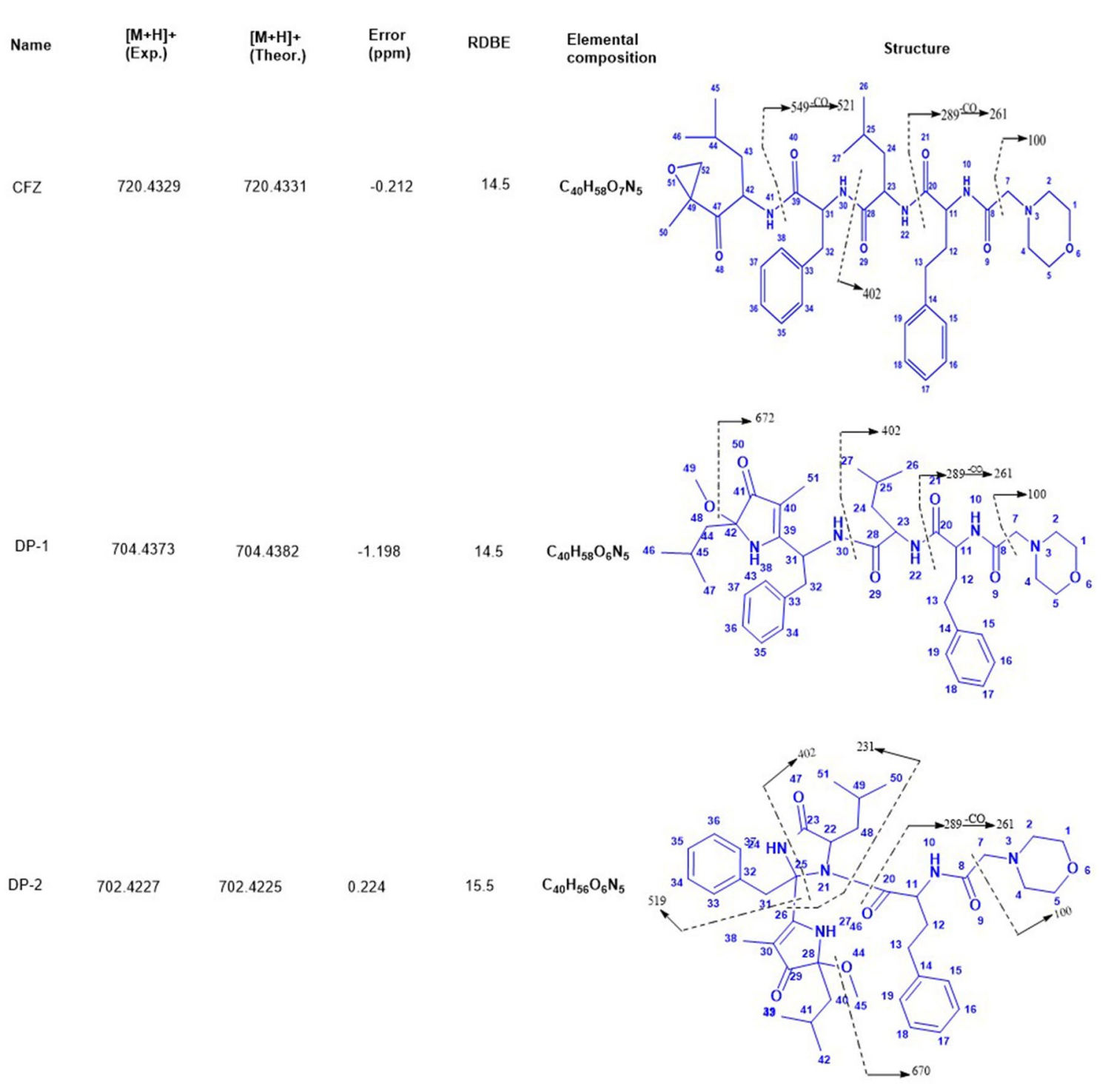

Fig. 6 Proposed structures of degradation products 
Fig. 7 a COSY spectrum of DP-2, b HMBC spectrum of DP-2
A
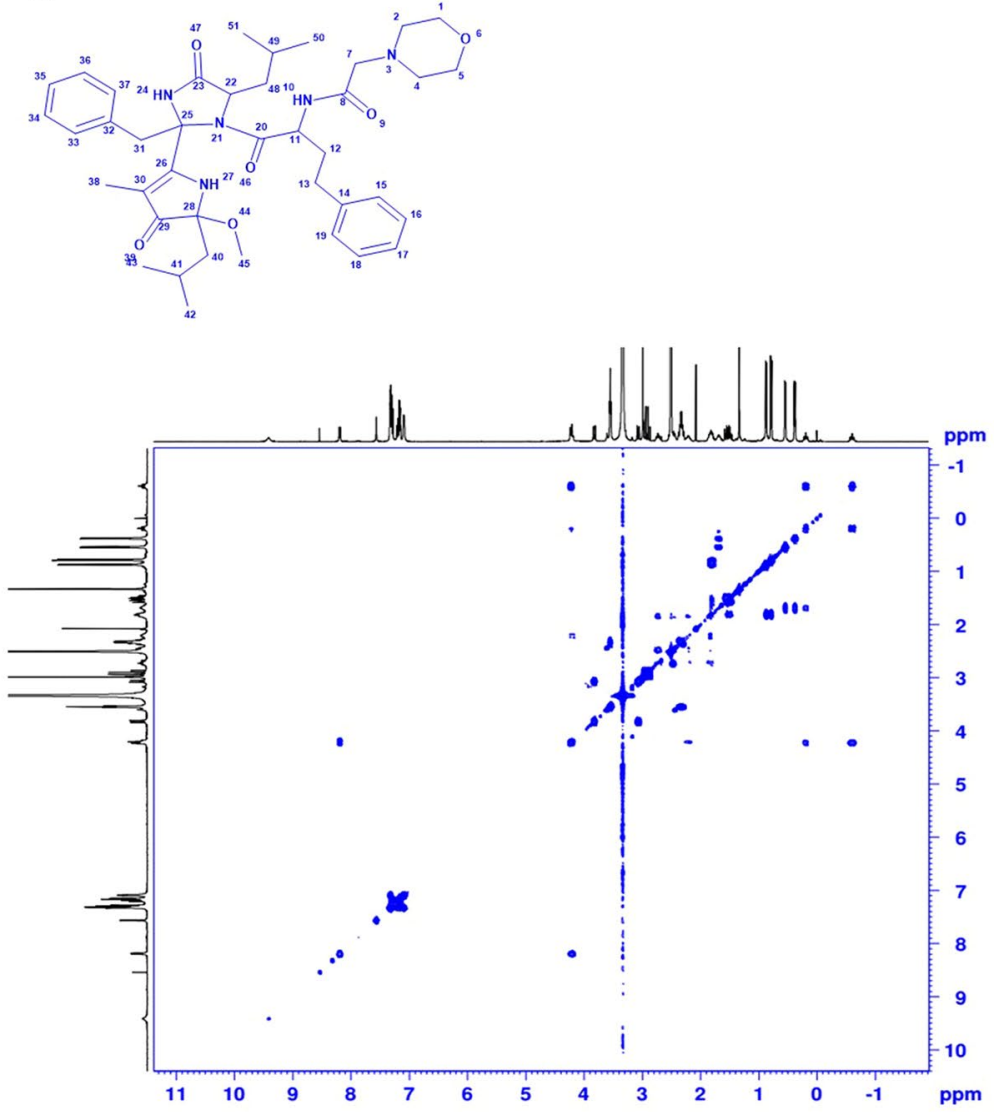

B
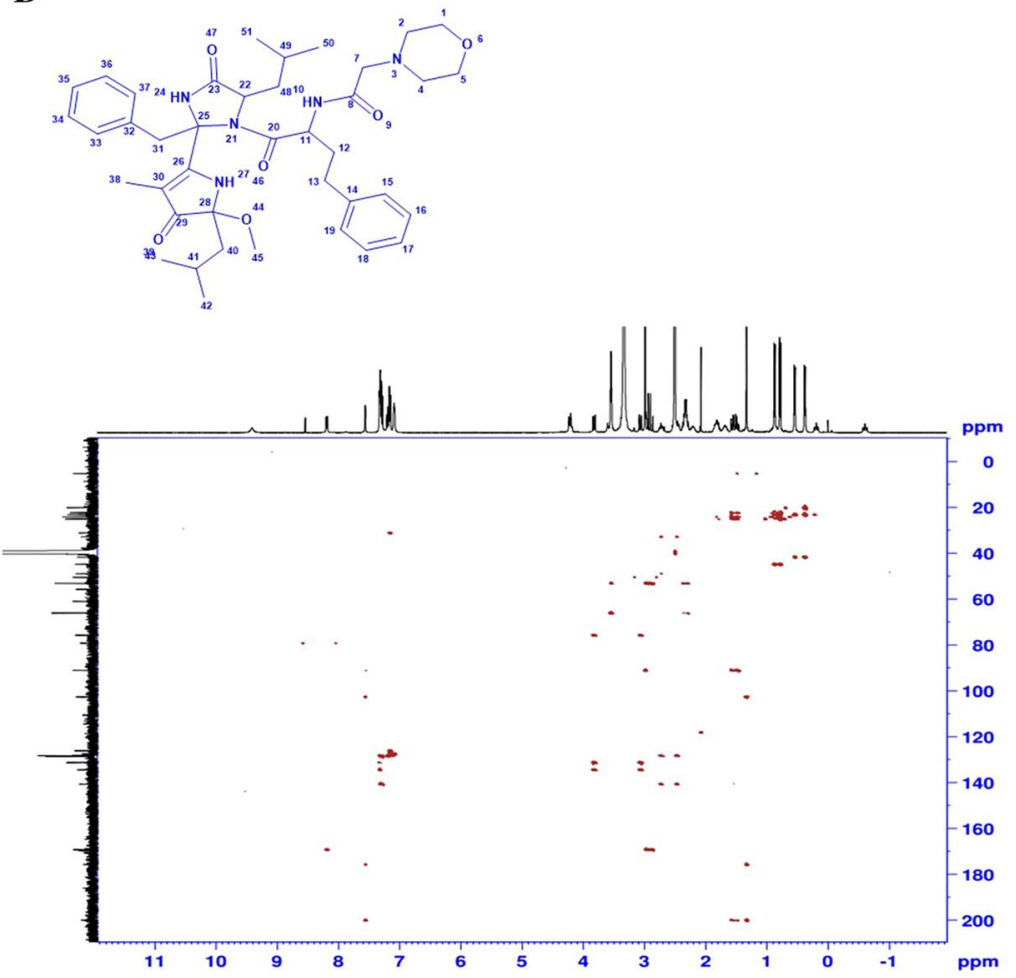
Table $2{ }^{1} \mathrm{H}$ and ${ }^{13} \mathrm{C}$ NMR data of DP-2

\begin{tabular}{|c|c|c|c|}
\hline \multicolumn{4}{|l|}{$D P-2$} \\
\hline Atom no & Type of atom & $1 \mathrm{H}$ chemical shift (ppm) coupling const $(J)$ & $\begin{array}{l}13 C \text { chemi- } \\
\text { cal shifts } \\
\text { (ppm) }\end{array}$ \\
\hline 1 & $\mathrm{CH} 2$ & $3.54(\mathrm{t}, 4.4 \mathrm{~Hz}, 2 \mathrm{H})$ & 66.02 \\
\hline 2 & $\mathrm{CH} 2$ & $2.32(\mathrm{~m}, 2 \mathrm{H})$ & 53.08 \\
\hline 3 & $\mathrm{~N}$ & - & - \\
\hline 4 & $\mathrm{CH} 2$ & $2.32(\mathrm{~m}, 2 \mathrm{H})$ & 53.08 \\
\hline 5 & $\mathrm{CH} 2$ & $3.54(\mathrm{t}, 4.4 \mathrm{~Hz}, 2 \mathrm{H})$ & 66.02 \\
\hline 6 & $\mathrm{O}$ & - & - \\
\hline 7 & $\mathrm{CH} 2$ & $2.89(\mathrm{~d}, 15.2 \mathrm{~Hz}, 1 \mathrm{H}) 2.93(\mathrm{~d}, 15.2 \mathrm{~Hz}, 1 \mathrm{H})$ & 60.94 \\
\hline 8 & C & - & 169.31 \\
\hline 9 & $\mathrm{O}$ & - & - \\
\hline 10 & $\mathrm{NH}$ & $8.17(\mathrm{~d}, 8.00 \mathrm{~Hz}, 1 \mathrm{H})$ & - \\
\hline 11 & $\mathrm{CH}$ & $4.20(\mathrm{~m}, 1 \mathrm{H})$ & 48.91 \\
\hline 12 & $\mathrm{CH} 2$ & $1.83(\mathrm{~m}, 1 \mathrm{H}) 2.20(\mathrm{~m}, 1 \mathrm{H})$ & 32.78 \\
\hline 13 & $\mathrm{CH} 2$ & $2.46(\mathrm{~m}, 1 \mathrm{H}) 2.72(\mathrm{~m}, 1 \mathrm{H})$ & 31.1 \\
\hline 14 & $\mathrm{C}$ & - & 140.66 \\
\hline 15 & $\mathrm{CH}$ & 7.14(m, 1H) & 128.28 \\
\hline 16 & $\mathrm{CH}$ & $7.29(\mathrm{~m}, 1 \mathrm{H})$ & 128.57 \\
\hline 17 & $\mathrm{CH}$ & $7.19(\mathrm{~m}, 1 \mathrm{H})$ & 126.1 \\
\hline 18 & $\mathrm{CH}$ & $7.29(\mathrm{~m}, 1 \mathrm{H})$ & 128.57 \\
\hline 19 & $\mathrm{CH}$ & 7.14(m, 1H) & 128.28 \\
\hline 20 & $\mathrm{C}$ & - & 170.55 \\
\hline 21 & $\mathrm{~N}$ & - & - \\
\hline 22 & $\mathrm{CH}$ & $4.23(\mathrm{~m}, 1 \mathrm{H})$ & 55.72 \\
\hline 22 & - & - & - \\
\hline 23 & $\mathrm{C}$ & - & 169.93 \\
\hline 24 & $\mathrm{NH}$ & 9.41 (broad singlet, $1 \mathrm{H}$ ) & - \\
\hline 25 & $\mathrm{C}$ & - & 75.72 \\
\hline 26 & $\mathrm{C}$ & - & 175.73 \\
\hline 27 & $\mathrm{NH}$ & $7.56(\mathrm{~s}, 1 \mathrm{H})$ & - \\
\hline 28 & $\mathrm{C}$ & - & 91.05 \\
\hline 29 & $\mathrm{C}$ & - & 200.01 \\
\hline 30 & $\mathrm{C}$ & - & 102.65 \\
\hline 31 & $\mathrm{CH} 2$ & $3.08(\mathrm{~d}, 13.6 \mathrm{~Hz}, 1 \mathrm{H}) 3.83(\mathrm{~d}, 13.6 \mathrm{~Hz}, 1 \mathrm{H})$ & 41.79 \\
\hline 32 & C & - & 134.42 \\
\hline 33 & $\mathrm{CH}$ & $7.08(\mathrm{~m}, 1 \mathrm{H})$ & 131.22 \\
\hline 34 & $\mathrm{CH}$ & $7.32(\mathrm{~m}, 1 \mathrm{H})$ & 128.16 \\
\hline 35 & $\mathrm{CH}$ & $7.31(\mathrm{~m}, 1 \mathrm{H})$ & 128.28 \\
\hline 36 & $\mathrm{CH}$ & $7.32(\mathrm{~m}, 1 \mathrm{H})$ & 128.16 \\
\hline 37 & $\mathrm{CH}$ & $7.08(\mathrm{~m}, 1 \mathrm{H})$ & 131.22 \\
\hline 38 & $\mathrm{CH} 3$ & $1.33(\mathrm{~s}, 3 \mathrm{H})$ & 5.23 \\
\hline 39 & $\mathrm{O}$ & - & - \\
\hline 40 & $\mathrm{CH} 2$ & $1.50(\mathrm{~m}, 2 \mathrm{H})$ & 44.74 \\
\hline 41 & $\mathrm{CH}$ & $1.80(\mathrm{~m}, 1 \mathrm{H})$ & 22.28 \\
\hline 42 & $\mathrm{CH} 3$ & $0.87(\mathrm{~d}, 6.70 \mathrm{~Hz}, 3 \mathrm{H})$ & 24.98 \\
\hline 43 & $\mathrm{CH} 3$ & $0.77(\mathrm{~d}, 6.58 \mathrm{~Hz}, 3 \mathrm{H})$ & 24.07 \\
\hline 44 & $\mathrm{O}$ & - & - \\
\hline 45 & $\mathrm{CH} 3$ & $2.98(\mathrm{~s}, 3 \mathrm{H})$ & 50.46 \\
\hline 46 & $\mathrm{O}$ & - & - \\
\hline 47 & 0 & - & - \\
\hline
\end{tabular}


Table 2 (continued)

\begin{tabular}{llll}
\hline$D P-2$ & & \\
\hline Atom no & Type of atom & $1 \mathrm{H}$ chemical shift $(\mathrm{ppm})$ coupling const $(\mathrm{J})$ & $\begin{array}{l}13 \mathrm{C} \text { chemi- } \\
\text { cal shifts } \\
(\mathrm{ppm})\end{array}$ \\
\hline 48 & $\mathrm{CH} 2$ & $-0.60(\mathrm{~m}, 1 \mathrm{H}) 0.18(\mathrm{~m}, 1 \mathrm{H})$ & 41.68 \\
49 & $\mathrm{CH}$ & $1.66(\mathrm{~m}, 1 \mathrm{H})$ & 23.07 \\
50 & $\mathrm{CH} 3$ & $0.53(\mathrm{~d}, 6.40 \mathrm{~Hz}, 3 \mathrm{H})$ & 20.11 \\
51 & $\mathrm{CH} 3$ & $0.36(\mathrm{~d}, 6.80 \mathrm{~Hz}, 3 \mathrm{H})$ & 23.1 \\
\hline
\end{tabular}

$s$ singlet, $d$ doublet, $t$ triplet, $m$ multiplet

Fig. 8 HSQC spectrum of DP-2

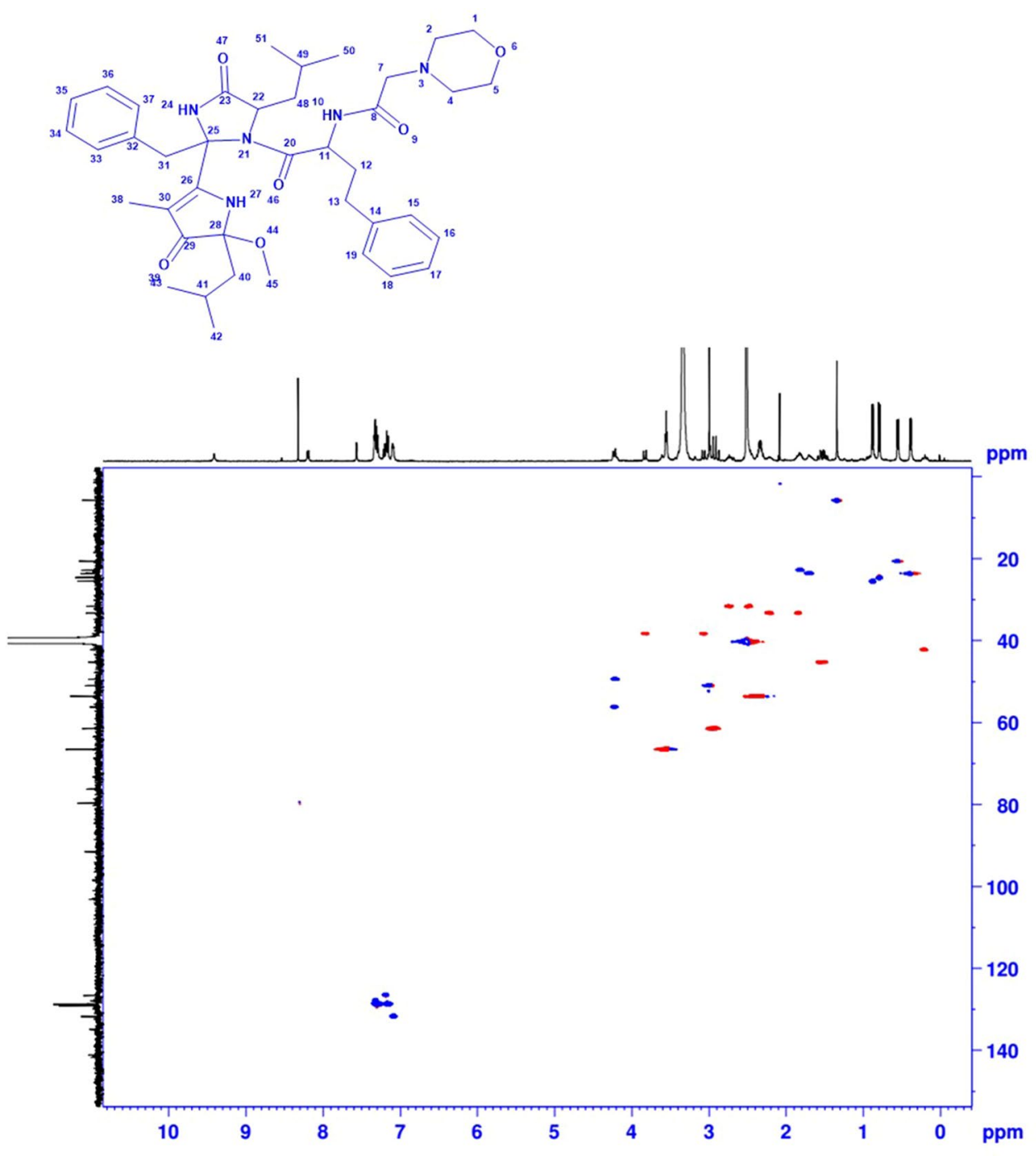




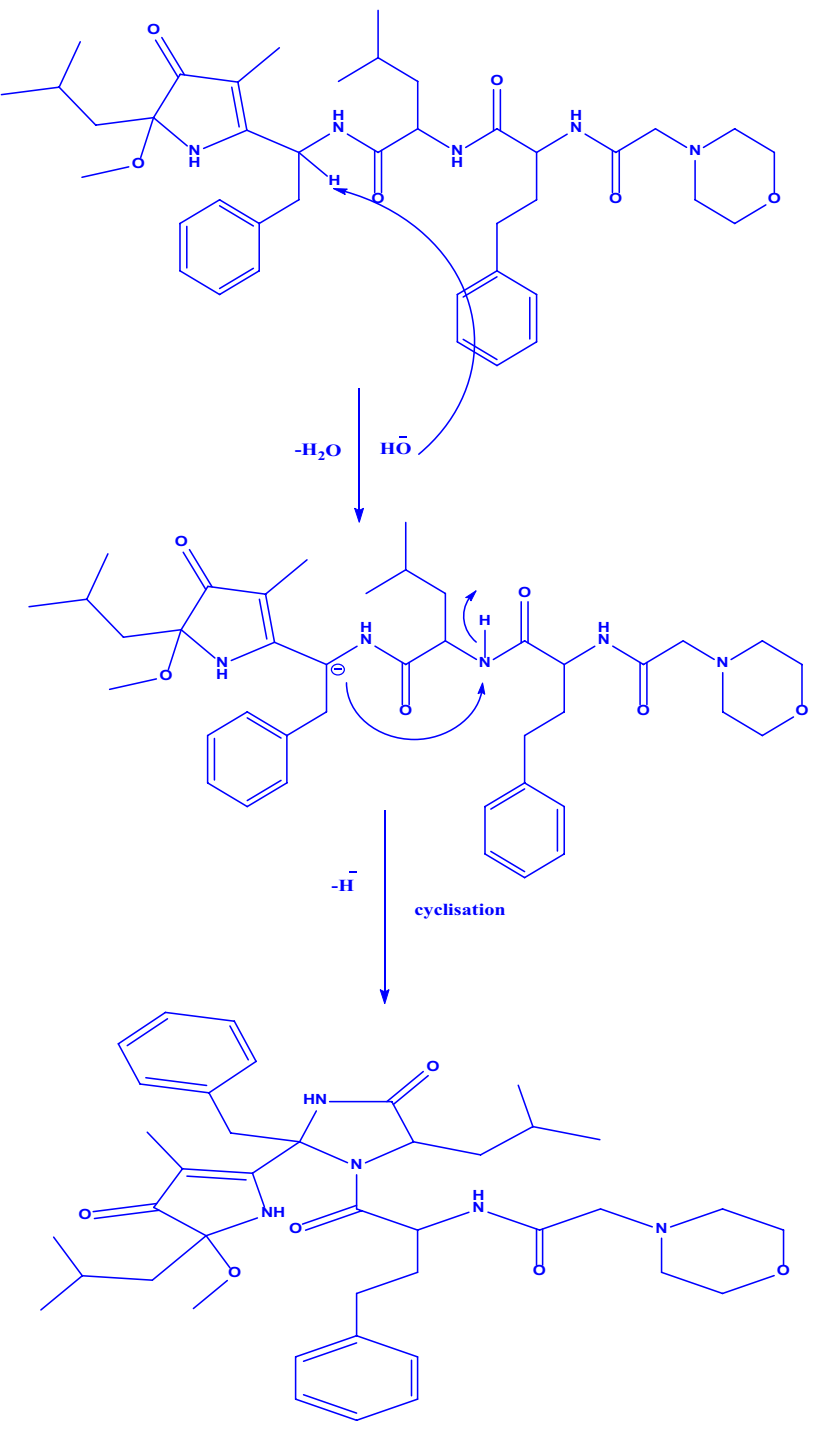

Fig. 9 Plausible mechanism of DP-2

\section{Supplementary data}

All the HR-MS/MS and NMR spectra are provided as supplementary data

Acknowledgements The authors would like to thank the management of GVK Biosciences Pvt. Ltd. for supporting this work.

Funding This study was funded by Vijay Bommuluri

\section{Compliance with ethical standards}

Conflicts of interest The authors declare that they have no competing interests.

Ethical approval This article does not contain any studies with human participants or animals performed by any of the authors.

\section{References}

1. Kortuem KM, Stewart AK (2013) Carfilzomib. Blood 121:893-897

2. Bilotti E (2013) Carfilzomib: a next-generation proteasome inhibitor for multiple myeloma treatment. Clin J Oncol Nurs 17(2):E35-E44

3. Sugumar D, Keller J, Vij R (2015) Targeted treatments for multiple myeloma: specific role of carfilzomib. Pharmacogenomics Pers Med 8:23-33

4. FDA KYPROLIS FDA prescribing information. Available from: http://www.accessdata.fda.gov/drugsatfda_docs/label /2015/202714s009lbl.pdf. Accessed 28 Apr 2018

5. EMA EMA KYPROLIS information. Available from: http://www. ema.europa.eu/docs/en_GB/document_library/EPAR_Produ ct_Information/human/003790/WC500197692.pdf. Accessed 28 Apr 2018

6. Teicher BA, Tomaszewski JE (2015) Proteasome inhibitors. Biochem Pharmacol 96:1-9

7. Sestak V, Roh J, Klepalova L, Kovarikova P (2016) A UHPLCUV-QTOF study on the stability of carfilzomib, a novel proteasome inhibitor. J Pharm Biomed Anal 124:365-373. https://doi. org/10.1016/j.jpba.2016.03.015

8. Wang Z, Yang J, Kirk C, Fang Y, Alsina M, Badros A, Papadopoulos K, Wong A, Woo T, Bomba D, Li J, Infante JR (2013) Clinical pharmacokinetics, metabolism, and drug-drug interaction of carfilzomib. Drug Metab Dispos 41:230-237

9. Yang J, Wang Z, Fang $Y$, Jiang J, Zhao F, Wong H, Bennett MK, Molineaux CJ, Kirk CJ (2011) Pharmacokinetics, pharmacodynamics, metabolism, distribution, and excretion of carfilzomib in rats. Drug Metab Dispos 39:1873-1882

10. Suzuki K, Ri M, Chou T, Sugiura I, Takezako N, Sunami K, Ishida T, Izumi T, Ozaki S, Shumiya Y, Ota K, lida S (2017) Carfilzomib, lenalidomide and dexamethasone in patients with heavily pretreated multiple myeloma: a phase 1 study in Japan. Cancer Sci 108:461-468

11. Park JE, Chun SE, Reichel D, Min JS, Lee SC, Han S, Ryoo G, Oh Y, Park SH, Ryu HM, Kim KB, Lee HY, Bae SK, Bae Y, Lee W (2017) Polymer micelle formulation for the proteasome inhibitor drug carfilzomib: anticancer efficacy and pharmacokinetic studies in mice. PLoS ONE 12:e0173247

12. ICH, ICH guidelines (1996) Q1B: Photostability testing of new drug substances and products. Available from: http://www.fda. gov/downloads/Drugs/GuidanceComplianceRegulatorylnforma tion/Guidances/ucm073373

13. ICH, ICH guidelines (2003) Q1A(R2): Stability testing of new drug substances and products (revision 2). Available from: http:// www.fda.gov/downloads/Regulatorylnformation/Guidances/ ucm128204.pdf

14. Singh S, Bakshi M (2000) Guidance on the conduct of stress tests to determine inherent stability of drugs. Pharm Technol Online $4: 1-14$

15. Min JS, Kim J, Kim JH, Kim D, Zheng YF, Park JE, Lee W, Bae SK (2017) Quantitative determination of carfilzomib in mouse plasma by liquid chromatography - tandem mass spectrometry and its application to a pharmacokinetic study. J Pharm Biomed Anal. https://doi.org/10.1016/j.jpba.2017.08.048

16. Phizackerley KM, Jumaa $M$, Lopalco $A$, Wolfe $B H$, Ablan $C D$, Stella VJ (2017) Mechanism of degradation of an a-keto-epoxide, a model for the warhead for various proteasome inhibitor anticancer agents. J Pharm Sci 1:2-3. https://doi.org/10.1016/j. xphs.2016.12.006

Publisher's Note Springer Nature remains neutral with regard to jurisdictional claims in published maps and institutional affiliations. 